\title{
pH-Potentiometric Investigation towards Chelating Tendencies of $p$-Hydroquinone and Phenol Iminodiacetate Copper(II) Complexes
}

\author{
Marios Stylianou, ${ }^{1}$ Anastasios D. Keramidas, ${ }^{1}$ and Chryssoula Drouza ${ }^{2}$ \\ ${ }^{1}$ Department of Chemistry, University of Cyprus, 1678 Nicosia, Cyprus \\ ${ }^{2}$ Agricultural Production and Biotechnology and Food Science, Cyprus University of Technology, P.O. Box 50329, 3603 Lemesos, Cyprus \\ Correspondence should be addressed to Chryssoula Drouza, chryssoula.drouza@cut.ac.cy
}

Received 27 January 2010; Accepted 23 March 2010

Academic Editor: Spyros P. Perlepes

Copyright ( $) 2010$ Marios Stylianou et al. This is an open access article distributed under the Creative Commons Attribution License, which permits unrestricted use, distribution, and reproduction in any medium, provided the original work is properly cited.

Copper ions in the active sites of several proteins/enzymes interact with phenols and quinones, and this interaction is associated to the reactivity of the enzymes. In this study the speciation of the $\mathrm{Cu}^{2+}$ with iminodiacetic phenolate/hydroquinonate ligands has been examined by $\mathrm{pH}$-potentiometry. The results reveal that the iminodiacetic phenol ligand forms mononuclear complexes

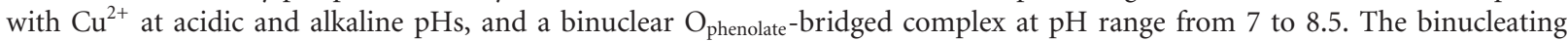
hydroquinone ligand forms only 2:1 metal to ligand complexes in solution. The $\mathrm{pK}$ values of the protonation of the phenolate oxygen of the two ligands are reduced about 2 units after complexation with the metal ion and are close to the pK values for the copper-interacting tyrosine phenol oxygen in copper enzymes.

\section{Introduction}

Copper ions in the active sites of proteins/enzymes mediate a broad scope of chemical processes including electron transfer, dioxygen uptake, storage, and transport and catalytic conversions [1]. When surveying the known copper enzymes and their functions, it is striking that their reactivity is typically linked to dioxygen or compounds directly synthesized from $\mathrm{O}_{2}$-like phenols and quinones [2-7].

For example, copper proteins are involved in reversible dioxygen binding in hemocyanin [8], two-electron reduction to peroxide coupled to oxidation of substrates in amine and galactose oxidases [9], biogenesis of novel metalloenzyme cofactors (e.g., topaquinone in amine oxidases) [10], activation of hydroxylation in tyrosinase [11], and proton pumping in cytochrome c oxidase [12].

Detailed study of the solid and solution chemistry of $\mathrm{Cu}^{2+}$ phenolate/hydroquinonate complexes is essential for better understanding of the coordination of the metal ion in the enzymes and the mechanisms of the enzymatic catalysis. Derivatives of phenol or hydroquinone containing nitrogen
[13-22] as donor atoms are the vast majority of the ligands used to model the active site of the copper enzymes. Despite the importance of phenolate/hydroquinonate chelating ligands as models of copper enzymes, ligands with other than nitrogen donor atoms such as aminocarboxylate derivatives of phenols, have been much less studied. These ligands exhibit very attractive features for modelling metal enzymes, such as the highly solubility in aqueous solution, forming stable complexes with metal ions and the similarity of the donor groups to those in biological systems. In addition, the one-electron oxidized $p$-semiquinone radical of the ligand 2,5-bis[N,N-bis(carboxymethyl)aminomethyl] hydroquinone $\left(\mathrm{H}_{6}\right.$ bicah $)$ has been stabilized in aqueous solution by ligation to metal ions [23] and thus serves as model for the enzymes that operate via a $p$-semiquinone radical, acting in one-electron transfer reactions, including cytochrome c and copper amine oxidases. In previous $\mathrm{pH}$-potentiometric studies [24] of $\mathrm{Cu}^{2+}$ with the phenol iminodiacetate ligand HBIDA (Scheme 1) the equilibrium calculations have been performed assuming that all the species of $\mathrm{Cu}^{2+}$ with HBIDA in solution at various $\mathrm{pHs}$ are mononuclear $1: 1$ and $1: 2$ 
metal to ligand complexes. A recent detailed crystallographic study [25] of the $\mathrm{Cu}^{2+}$-phenol iminodiacetate $\mathrm{H}_{4}$ cacp, $\mathrm{H}_{4}$ cah and $\mathrm{H}_{6}$ bicah (Scheme 1) complexes isolated at a $\mathrm{pH}$ range

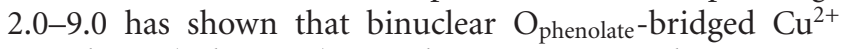
complexes (Scheme 2) are also present in solution. It is apparent that previous $\mathrm{pH}$-potentiometric studies of these systems should be repeated including also the dinuclear species in the calculations.

Herein, we describe the $\mathrm{pH}$-potentiometric studies of $\mathrm{Cu}^{2+}$ with the iminodiacetate phenolate tripod ligands $\mathrm{H}_{4}$ cacp and $\mathrm{H}_{6}$ bicah. In contrast to $\mathrm{H}_{4}$ cacp, $\mathrm{H}_{6}$ bicah exhibits two metal ion binding sites bridged through the hydroquinone moiety. The potentiometric study showed that only the $\mathrm{H}_{4}$ cacp ligand forms in solution $\mathrm{O}_{\text {phenolate-bridged }}$ binuclear complexes, which is also in agreement with the previous crystallographic study [25]. The $\mathrm{pK}$ values of the protonation of the phenolate oxygen of the two ligands reduced about 2 units after complexation with the metal ion are close to the $\mathrm{pK}$ values for the copper-interacting tyrosine phenol oxygen in copper enzymes, such as glyoxal oxidase [26].

\section{Experimental Section}

2.1. Materials. Copper(II) acetate monohydrate, p-hydroquinone, 4-hydroxybenzoic acid, iminodiacetic acid, paraformaldehyde, potassium chloride, and potassium hydrogen phthalate were obtained from Aldrich. Sodium hydroxide and hydrogen chloride were purchased from Merck. All chemicals were reagent grade and used without further purification.

2.2. Ligand Preparation. The ligands referred to this study 2,5-bis[ $N, N^{\prime}$-bis(carboxymethyl)aminomethyl]-hydroquinone $\left(\mathrm{H}_{6}\right.$ bicah $)$ and 2-[N,N'-bis(carboxymethyl)aminomethyl]-4-carboxyphenol ( $\left.\mathrm{H}_{4} \mathrm{cacp}\right)$ were synthesized based on the Mannich type reaction reported in the literature $[27,28]$. The synthesis of the organic ligands (Scheme 1) was performed under inert nitrogen atmosphere and their purity was checked and confirmed by means of ${ }^{1} \mathrm{H}$ NMR spectroscopy. ${ }^{1} \mathrm{H}$-NMR spectra were recorded on a 300.13 MHz Avance Brucker spectrometer.

\subsection{Potentiometric Studies and Computational Data Analysis.} The potentiometric equilibrium measurements of $\mathrm{H}_{4} \mathrm{cacp}$ and $\mathrm{H}_{6}$ bicah ligands in the absence and in the presence of metal ions were carried out with a JENWAY $3020 \mathrm{pH}$ meter fitted with an $\mathrm{Ag}-\mathrm{AgCl}$ reference electrode in saturated $\mathrm{KCl}$ solution. A glass electrode was calibrated as a hydrogen concentration probe by titrating known amounts of $\mathrm{HCl}$ with $\mathrm{CO}_{2}$-free $\mathrm{NaOH}$ solution, and the equivalence point was determined by Gran's method which yields the standard potential $E^{\circ}$ of the electrode, using the GLEE computational program [29]. The actual concentration of $\mathrm{NaOH}\left(0.157 \mathrm{~mol} \mathrm{dm}^{-3}\right)$ was standardized by titration with potassium hydrogen phthalate, and the $\mathrm{HCl}$ solution $\left(0.111 \mathrm{~mol} \mathrm{dm}^{-3}\right)$ was standardized by titration of the standard $\mathrm{NaOH}$ solution. The temperature was maintained at
$298 \mathrm{~K}$ and the ionic strength of each experimental sample was adjusted to $0.100 \mathrm{~mol} \mathrm{dm}^{-3}$ with the addition of $\mathrm{KCl}$ supporting electrolyte. Typical concentrations of experimental solutions were $5.00 \mathrm{mmol} \mathrm{dm}^{-3}$ in ligand with molar concentration of copper (II) ion half, equivalent, and twice to that of the ligand. Degassed distilled water was used for the preparation of the solutions and the oxygen and carbon dioxide contamination of the reaction mixtures from the atmosphere was avoided by continuous passing of purified nitrogen gas in the reaction cell.

The proton association constants of $\mathrm{H}_{4}$ cacp and $\mathrm{H}_{6}$ bicah ligands and the formation constants of $1: 1\left(\mathrm{H}_{4} \mathrm{cacp}: \mathrm{Cu}^{2+}\right)$

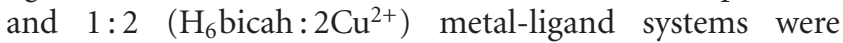
obtained using the program TIRMET which is a computational program based on mass-balance and charge-balance equations, written in our laboratory according to the basic principles first reported by Martell and Motekaitis [30, 31]. In this program the input consists of the components and their concentrations, the initial values of the equilibrium constants for each species considered to be present, the potentiometric equilibrium data determined experimentally, and conditions of the potentiometric experimental procedure $\left(E^{\circ}, \mathrm{pK}_{w}=13.78\right.$ at $\left.298 \mathrm{~K}, \gamma=0.78\right)$. The program sets up simultaneous mass-balance equations for all components at each neutralization value involving the concentration of acid added to the assay and solves for each species present in the $\mathrm{pH}$ region 2.00-10.0. Then, equilibrium constants are varied in order to minimize the differences between the calculated and observed values, resulting in the fitting of the calculated results to the experimental curves. The concentration stability constants, $\beta_{p q r}=\left[\mathrm{M}_{p} \mathrm{~L}_{q} \mathrm{H}_{r}\right] /[\mathrm{M}]^{p}[\mathrm{~L}]^{q}[\mathrm{H}]^{r}$, were considered to be estimated according to the model proposed by the computational program PSEQUAD [32]. The species considered present in the assays are those expected to be formed according to established principles of coordination chemistry including the formation of deprotonated and protonated metal chelates, respectively [24, 3335]. All potentiometric titrations were performed three times for each system (about 100 data points each) in the $\mathrm{pH}$ range 2.00-10.0 without significant variation.

\section{Results and Discussion}

3.1. Ligands. Potentiometric titrations of phenol $\left(\mathrm{H}_{4} \mathrm{cacp}\right)$ and $p$-hydroquinone $\left(\mathrm{H}_{6}\right.$ bicah) iminodiacetate derivatives indicate stepwise protonation steps arising from their characteristic functional groups, amine, carboxylates, and phenolate, in the measurable $\mathrm{pH}$ range. The protonation constants (overall stability protonation constants $\log \beta$ ) are listed in Tables 1 and 2, respectively, and their distribution speciation diagrams are illustrated in Figure 1.

The $\mathrm{pH}$-metric titration curve of $\mathrm{H}_{4}$ cacp indicates three major protonation steps due to the phenolate or the benzoiccarboxylate oxygen group, the carboxylate oxygen group, and the amino group with $\mathrm{pK}_{a}$ values 8.47, 4.84, and 2.42, respectively (Table 1 ). The low $\mathrm{pK}_{a}(2.42)$ value attributed to the amine nitrogen atom demonstrates intramolecular hydrogen bonding between the deprotonated amino group 


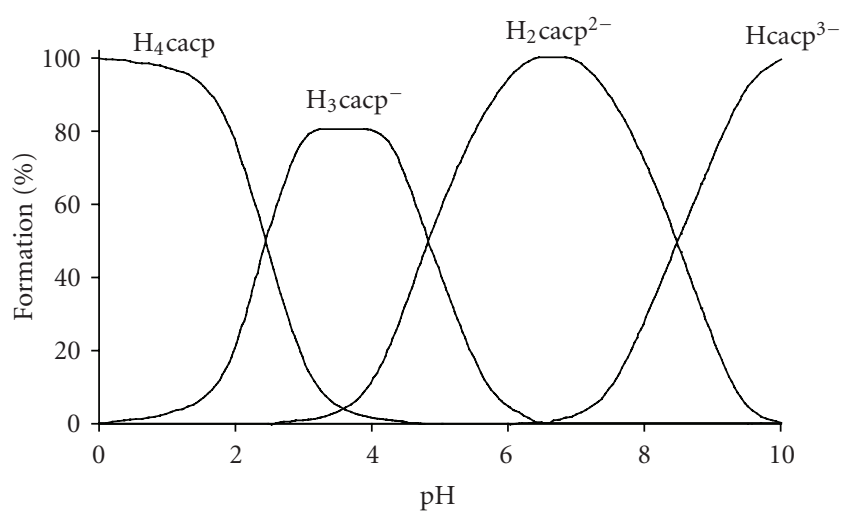

(a)

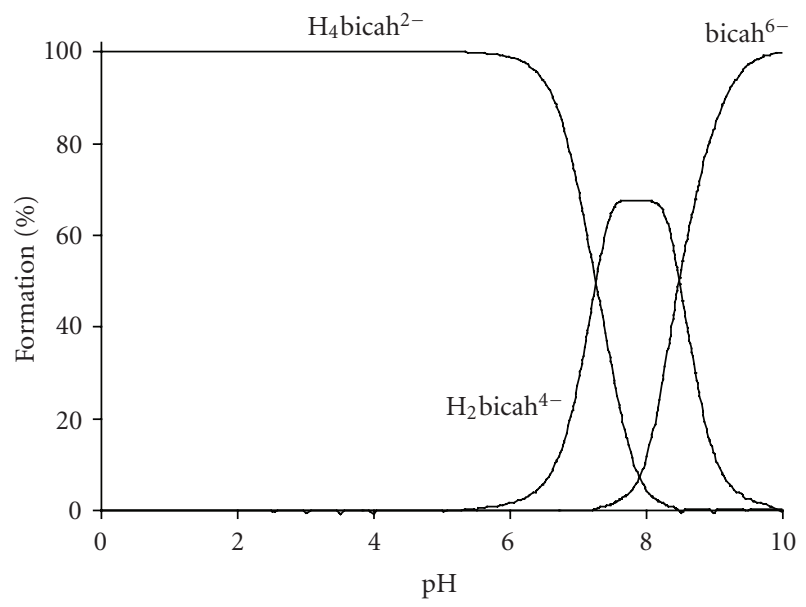

(b)

FIGURE 1: Species distribution (\% formation) for the phenol (a) and $p$-hydroquinone (b) iminodiacetate ligands as a function of $\mathrm{pH}$ over the range $2.00-10.0$ at molar concentration $5.00 \mathrm{mmol} \mathrm{dm}^{-3}\left(25^{\circ} \mathrm{C}\right.$, $I=0.10 \mathrm{~mol} \mathrm{dm}^{-3} \mathrm{KCl}, \mathrm{pK}_{w}=13.78$, and $\left.\gamma=0.78\right)$.

TABle 1: Compositions, overall stability formation constants (log $\beta)$, and acidity constants $\left(\mathrm{pK}_{a}\right)$ for the species formed in $H_{4}$ cacp and $\mathrm{Cu}(\mathrm{II})-\mathrm{H}_{4}$ cacp system, over the $\mathrm{pH}$ range $2.00-10.0$ thus obtained from the potentiometric study $\left(25^{\circ} \mathrm{C}, \mathrm{I}=0.10 \mathrm{moldm} \mathrm{m}^{-3} \mathrm{KCl}\right.$, $\mathrm{pK}_{w}=13.78$, and $\gamma=0.78$ ).

\begin{tabular}{lccc}
\hline$(p, q, r)$ & Species & $\log \beta$ & $\mathrm{pK}_{a}$ \\
\hline$(0,1,1)$ & {$\left[\mathrm{H}_{2} \text { cacp }\right]^{2-}$} & $8.40 \pm 0.01$ & $8.47^{\mathrm{a}}$ \\
$(0,1,2)$ & {$\left[\mathrm{H}_{3} \mathrm{cacp}\right]^{-}$} & $13.18 \pm 0.04$ & $4.84^{\mathrm{b}}$ \\
$(0,1,3)$ & {$\left[\mathrm{H}_{4}\right.$ cacp $]$} & $15.56 \pm 0.02$ & $2.42^{\mathrm{c}}$ \\
$(1,1,-1)$ & {$[\mathrm{Cu}(\mathrm{Hcacp})(\mathrm{OH})]^{2-}$} & $8.17 \pm 0.01$ & \\
$(2,2,0)$ & {$\left[\mathrm{Cu}_{2}(\mathrm{Hcacp})_{2}\right]^{2-}$} & $11.26 \pm 0.02$ & \\
$(1,1,0)$ & {$\left[\mathrm{Cu}\left(\mathrm{Hcacp}^{2}\left(\mathrm{H}_{2} \mathrm{O}\right)\right]^{-}\right.$} & $14.58 \pm 0.02$ & \\
$(1,2,2)$ & {$\left[\mathrm{Cu}\left(\mathrm{H}_{2} \mathrm{cacp}\right)_{2}\right]^{2-}$} & $17.62 \pm 0.02$ & \\
$(1,1,1)$ & {$\left[\mathrm{Cu}\left(\mathrm{H}_{2}\right.\right.$ cacp $\left.)\left(\mathrm{H}_{2} \mathrm{O}\right)\right]$} & $22.94 \pm 0.01$ & \\
\hline
\end{tabular}

${ }^{a}$ Phenolate or aromatic carboxylate oxygen group, ${ }^{b}$ carboxylate oxygen group, ${ }^{c}$ amine nitrogen group.

and the phenolic hydrogen. Such bonding stabilizes the deprotonated form of the nitrogen and thus facilitates loss of the hydrogen ion as shown by the lower $\mathrm{pK}_{a}$ value which is similar to that found for an analogue ligand $[N-(\mathrm{o}-$ hydroxybenzyl)iminodiacetic acid] [24](HBIDA, Scheme 1) (2.34) while for the nonphenolic, iminodiacetic acid (ida) the corresponded value is 2.94 [33]

The $\mathrm{pH}$-metric titration of the symmetric bis-substituted iminodiacetate $p$-hydroquinone derivative $\mathrm{H}_{6}$ bicah gave two steps each one corresponding to two successive protonation of the two phenolate oxygens and the two carboxylate groups with $\mathrm{pK}_{a}$ values 8.47 and 7.26 , respectively (Table 2 ). It was not possible to determine the $\mathrm{pK}_{a}$ value for the amine nitrogen group because this value was very low.

3.2. $\mathrm{Cu}(\mathrm{II})-\mathrm{H}_{4}$ cacp. The $\mathrm{Cu}(\mathrm{II})-\mathrm{H}_{4}$ cacp titration curves were evaluated on the assumption of the formation of various $1: 1,1: 2$ and $2: 1$ metal to ligand species with different protonation steps. The extensive crystallographic study of the isolated complexes from solutions of $\mathrm{Cu}$ (II)- $\mathrm{H}_{4}$ cacp at various pHs reported by Stylianou et al. [25] was also used for the better suggestion of the species in solution (Scheme 2). The best fit with the experimental data (Figure 2(a)) was obtained with the speciation model listed in Table 1. Species distribution curves for the complexes formed in the $\mathrm{Cu}(\mathrm{II})$ $\mathrm{H}_{4}$ cacp system as a function of $\mathrm{pH}$ are depicted in Figure 3.

$\mathrm{Cu}$ (II) ion forms with $\mathrm{H}_{4}$ cacp three major mononuclear species, the protonated $\left[\mathrm{Cu}\left(\mathrm{H}_{2} \mathrm{cacp}\right)\left(\mathrm{H}_{2} \mathrm{O}\right)\right]$ at $\mathrm{pH}$ below 5.0, the deprotonated $\left[\mathrm{Cu}(\mathrm{Hcacp})\left(\mathrm{H}_{2} \mathrm{O}\right)\right]^{-}$at $\mathrm{pH}$ between 5.0 and 6.5 the mono-hydroxo species $[\mathrm{Cu}(\mathrm{Hcacp})(\mathrm{OH})]^{2-}$ at $\mathrm{pH}$ above 9.0 and a minor $1: 2$ metal to ligand $\left[\mathrm{Cu}\left(\mathrm{H}_{2} \mathrm{cacp}\right)_{2}\right]^{2-}$ species at $\mathrm{pH} 5$.

The process from the deprotonated mononuclear species to the protonated one, which corresponds to the consumption of one $\mathrm{H}^{+}$per molecule of complex equation (1), is accompanied by a color change from green to blue attributed to the protonation of the phenolic oxygen. The protonation of the phenolic oxygen will result in weakening or nonbonding of the $\mathrm{Cu}-\mathrm{OH}$ (phenol) bond which is in agreement with the color change (the mononuclear nonphenolic amino acetate complexes of $\mathrm{Cu}^{2+}$ at acidic $\mathrm{pHs}$ exhibit blue color). The crystallographic data of the complex isolated at $\mathrm{pH} 3.2$ [25] confirm the weak interaction between the protonated phenol oxygen atom and the metal ion $[\mathrm{Cu}-\mathrm{OH}(\mathrm{phenol})$, 2.529(2) $\AA]$ :

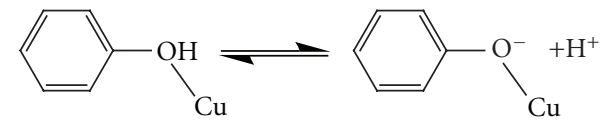

The estimated $\mathrm{pK}_{a}$ involved in this protonation step is $5.22 \pm 0.02$ and is comparable to that calculated by UVvis spectroscopic studies and was found to be $5.91 \pm 0.05$ [25]. The overall stability formation constants of complexes $\left[\mathrm{Cu}(\mathrm{Hcacp})^{-}\right]$and $\left[\mathrm{Cu}\left(\mathrm{H}_{2} \mathrm{cacp}\right)\left(\mathrm{H}_{2} \mathrm{O}\right)\right]$ are greater than those of the iminodiacetate copper (II) complexes [Cu(ida)] $(\log \beta 10.42)$ and $[\mathrm{Cu}(\mathrm{H})(\mathrm{ida})](\log \beta$ 12.35) [33]. The higher stability is ascribable to the coordination of the phenolate oxygen atom. This is also supported by the X-ray crystallographic studies which show that the deprotonated form, even at low pHs, strongly interacts with the metal ion. In addition, the planar configuration of the phenyl ring fixes 


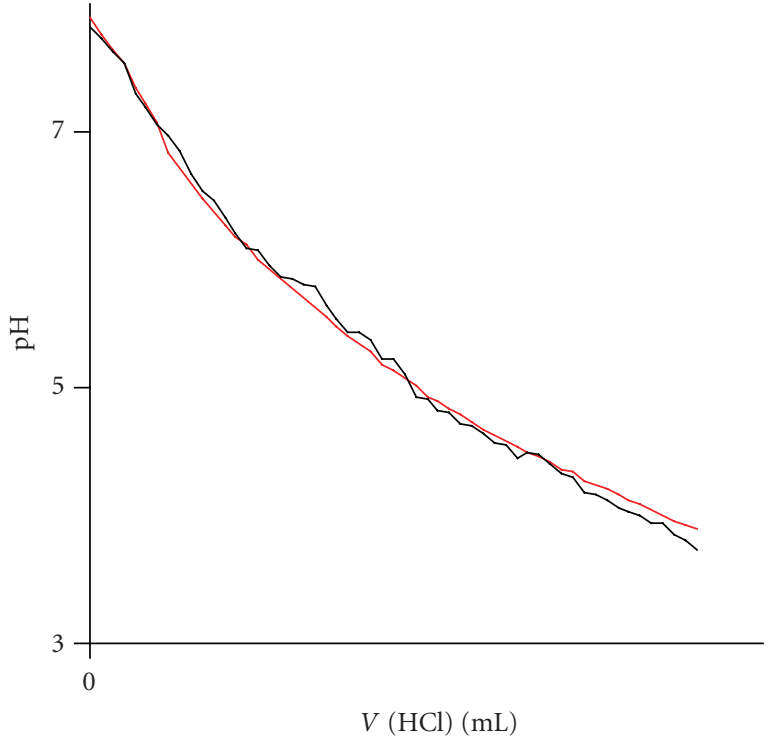

(a)

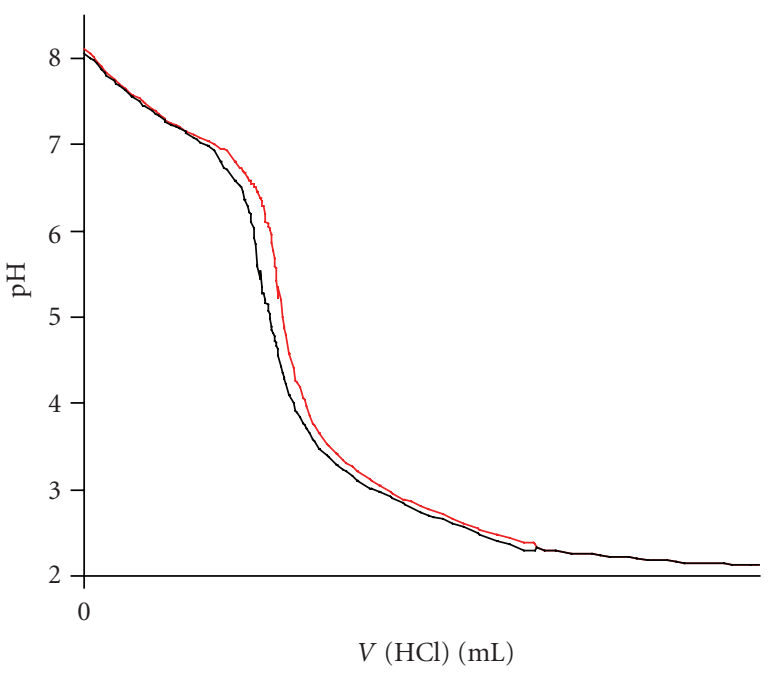

(b)

FIgURE 2: Potentiometric titrations for the $\mathrm{Cu}(\mathrm{II})-\mathrm{H}_{4} \operatorname{cacp}(1: 1)$ and $\mathrm{Cu}(\mathrm{II})-\mathrm{H}_{6}$ bicah $(2: 1)$ systems (a) and (b), respectively) as a function of $\mathrm{pH}$ over the range $2.00-10.0$ at molar concentration $2.50 \mathrm{mmol} \mathrm{dm}{ }^{-3}$ based on ligand $\left(25^{\circ} \mathrm{C}, I=0.10 \mathrm{~mol} \mathrm{dm}^{-3} \mathrm{KCl}, \mathrm{pK}_{w}=13.78, \gamma=0.78\right.$, and $\mathrm{HCl}=0.111 \mathrm{mmol} \mathrm{dm}^{-3}$ ). The line denoted with black colour refers to the experimental titration curve while the red refers to the computational fitting of the obtained experimental data.

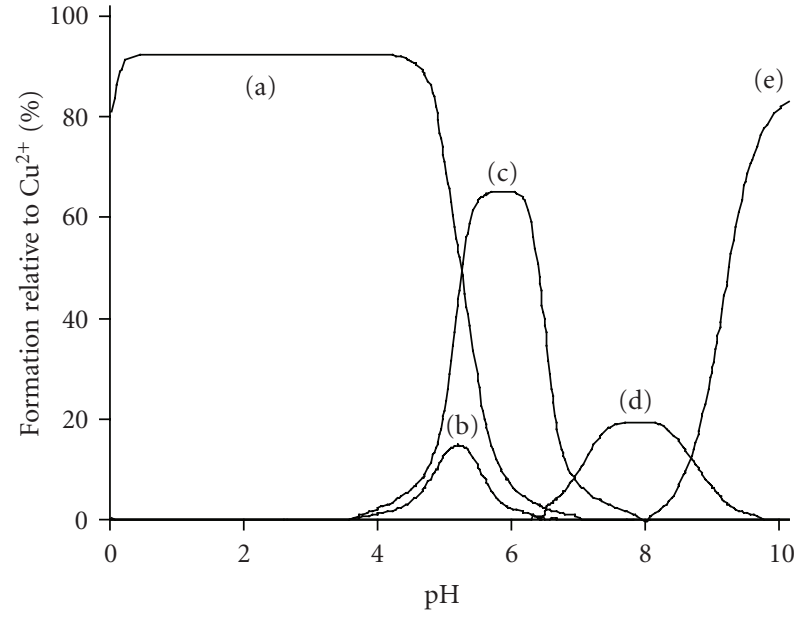

Figure 3: Species distribution (\% formation relative to $\mathrm{Cu}^{2+}$ ) in the $\mathrm{Cu}(\mathrm{II})-\mathrm{H}_{4} \mathrm{cacp}$ system at equimolar concentration $\left(5.00 \mathrm{mmol} \mathrm{dm}^{-3}\right)$ as a function of $\mathrm{pH}$ over the range 2.00$10.0\left(25^{\circ} \mathrm{C}, I=0.10 \mathrm{~mol} \mathrm{dm}{ }^{-3} \mathrm{KCl}, \mathrm{pK}_{w}=13.78, \gamma=0.78\right)$. The $\mathrm{Cu}(\mathrm{II})$ species are as follows: (a) $\left[\mathrm{Cu}\left(\mathrm{H}_{2} \mathrm{cacp}\right)\left(\mathrm{H}_{2} \mathrm{O}\right)\right]$, (b) $\left[\mathrm{Cu}\left(\mathrm{H}_{2} \mathrm{cacp}\right)_{2}\right]^{2-}$, (c) $\left[\mathrm{Cu}(\mathrm{Hcacp})\left(\mathrm{H}_{2} \mathrm{O}\right)\right]^{-}$, (d) $\left[\mathrm{Cu}_{2}(\mathrm{Hcacp})_{2}\right]^{2-}$, and $(\mathrm{e})[\mathrm{Cu}(\mathrm{Hcacp})(\mathrm{OH})]^{2-}$.

the orientation of the flexible carboxylate groups in positions favorable to chelating, especially in the case of the copper(II) ion which forms stable complexes in an octahedral/or square pyramidal coordination geometry pattern [36].

One very significant result of this potentiometric titration study is the detection of the dimeric species

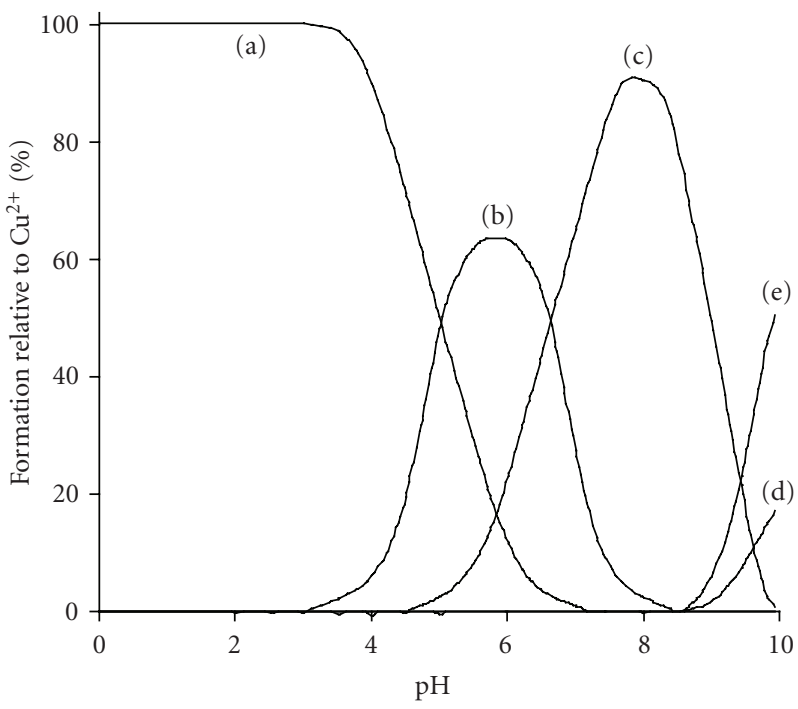

Figure 4: Species distribution (\% formation relative to $\mathrm{Cu}^{2+}$ ) in the $\mathrm{Cu}(\mathrm{II})-\mathrm{H}_{6}$ bicah system with metal-to-ligand molar ratio $1: 2$ concentration $\left(\mathrm{H}_{6}\right.$ bicah $\left.5.00 \mathrm{mmol} \mathrm{dm}^{-3}\right)$ as a function of $\mathrm{pH}$ over the range $2.00-10.0\left(25^{\circ} \mathrm{C}, I=0.10 \mathrm{~mol} \mathrm{dm}^{-3} \mathrm{KCl}\right.$, $\mathrm{pK}_{\mathrm{w}}=13.78$, and $\left.\gamma=0.78\right)$. The $\mathrm{Cu}(\mathrm{II})$ species are as follows: (a) $\left[\mathrm{Cu}_{2}\left(\mathrm{H}_{2}\right.\right.$ bicah $\left.)\left(\mathrm{H}_{2} \mathrm{O}\right)_{2}\right]$, (b) $\left[\mathrm{Cu}_{2}(\mathrm{Hbicah})\left(\mathrm{H}_{2} \mathrm{O}\right)_{2}\right]^{-}$, (c) $\left[\mathrm{Cu}_{2}(\text { bicah })\left(\mathrm{H}_{2} \mathrm{O}\right)_{2}\right]^{2-}$, (d) $\left[\mathrm{Cu}_{2} \text { (bicah) }(\mathrm{OH})\left(\mathrm{H}_{2} \mathrm{O}\right)\right]^{3-}$, and (e) $\left[\mathrm{Cu}_{2}(\text { bicah })(\mathrm{OH})_{2}\right]^{4-}$.

$\left[\mathrm{Cu}_{2}(\mathrm{Hcacp})_{2}\right]^{2-}$. Previous potentiometric studies have postulated that the dimeric complexes are not favored in solution because of steric effects and electrostatic destabilization which do not allow a dimerization process [35]. Harris et 
<smiles>O=C([O-])C[NH+](CC(=O)O)Cc1ccccc1O</smiles>

HBIDA<smiles>O=C([O-])C[NH+](CC(=O)O)Cc1cc(C(=O)O)ccc1O</smiles><smiles>O=C([O-])C[NH+](CC(=O)O)Cc1cc(O)ccc1O</smiles>

$\mathrm{H}_{4} \mathrm{cah}$<smiles>O=C([O-])C[NH+](CC(=O)O)Cc1cc(O)c(C[NH+](CC(=O)O)CC(=O)O)cc1O</smiles>

SCHEme 1: Iminodiacetic derivatives of phenol/p-hydroquinone ligands with their abbreviations. The ligands referred to the potentiometric/stability studies are denoted in parentheses.

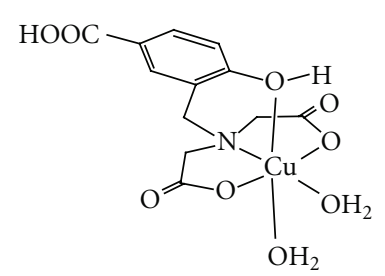

$\left[\mathrm{Cu}\left(\mathrm{H}_{2} \mathrm{cacp}\right)\left(\mathrm{H}_{2} \mathrm{O}\right)_{2}\right]$

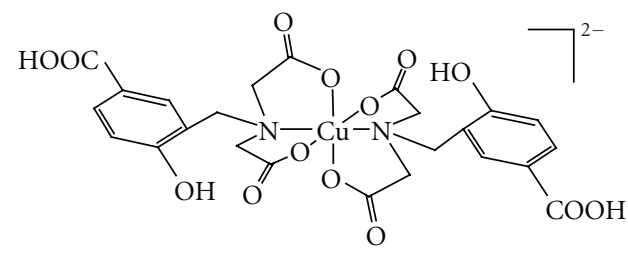

$\left[\mathrm{Cu}\left(\mathrm{H}_{2} \mathrm{Cacp}\right)_{2}\right]^{2-}$

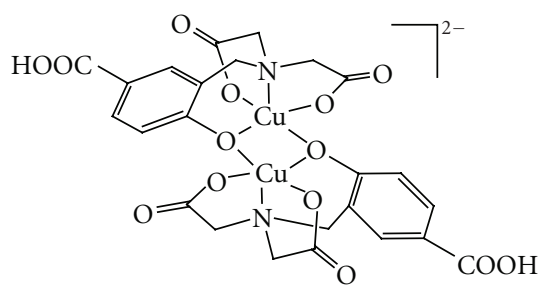

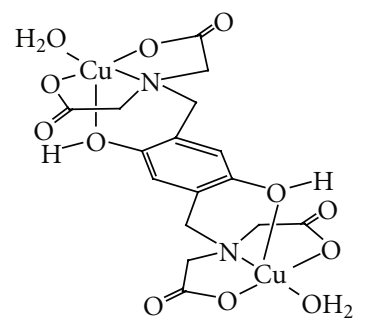

$\left[\mathrm{Cu}_{2}\left(\mathrm{H}_{2}\right.\right.$ bicah $\left.)\left(\mathrm{H}_{2} \mathrm{O}\right)_{2}\right]$

$\left[\mathrm{Cu}_{2}(\mathrm{Hcacp})_{2}\right]^{2-}$

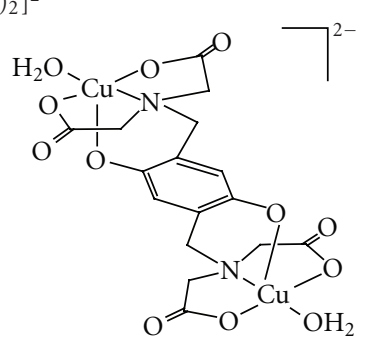

$\left[\mathrm{Cu}_{2}(\mathrm{Hbicah})\left(\mathrm{H}_{2} \mathrm{O}\right)_{2}\right]^{2-}$

Scheme 2: Molecular drawings of the structures of the phenol and $p$-hydroquinone iminodiacetate copper(II) complexes, isolated at a pH range 2.0-9.0 according to a recent detailed crystallographic study [25]. 
TABle 2: Compositions, overall stability formation constants $(\log \beta)$, and acidity constants $\left(\mathrm{pK}_{a}\right)$ for the species formed in $\mathrm{H}_{6}$ bicah and $\mathrm{Cu}(\mathrm{II})-\mathrm{H}_{6}$ bicah system, over the $\mathrm{pH}$ range 2.00 10.0 thus obtained from the potentiometric study $\left(25^{\circ} \mathrm{C}, I=\right.$ $0.10 \mathrm{~mol} \mathrm{dm}^{-3} \mathrm{KCl}, \mathrm{p} K_{w}=13.78$, and $\left.\gamma=0.78\right)$.

\begin{tabular}{lccc}
\hline$(p, q, r)$ & Species & $\log \beta$ & $\mathrm{pK}_{a}$ \\
\hline$(0,1,0)$ & {$\left[\mathrm{H}_{2} \text { bicah }\right]^{4-}$} & $8.41 \pm 0.02$ & $8.47^{\mathrm{a}}$ \\
$(0,1,2)$ & {$\left[\mathrm{H}_{4} \text { bicah }\right]^{2-}$} & $13.40 \pm 0.01$ & $7.26^{\mathrm{b}}$ \\
$(2,1,-2)$ & {$\left[\mathrm{Cu}_{2}(\text { bicah })(\mathrm{OH})_{2}\right]^{4-}$} & $11.57 \pm 0.15$ & \\
$(2,1,-1)$ & {$\left[\mathrm{Cu}_{2}(\text { bicah })\left(\mathrm{H}_{2} \mathrm{O}\right)(\mathrm{OH})\right]^{3-}$} & $15.72 \pm 0.11$ & \\
$(2,1,0)$ & {$\left[\mathrm{Cu}_{2}(\text { bicah })\left(\mathrm{H}_{2} \mathrm{O}\right)_{2}\right]^{2-}$} & $32.90 \pm 0.16$ & \\
$(2,1,1)$ & {$\left[\mathrm{Cu}_{2}(\mathrm{Hbicah})\left(\mathrm{H}_{2} \mathrm{O}\right)_{2}\right]^{-}$} & $39.33 \pm 0.16$ & \\
$(2,1,2)$ & {$\left[\mathrm{Cu}_{2}\left(\mathrm{H}_{2}\right.\right.$ bicah $\left.)\left(\mathrm{H}_{2} \mathrm{O}\right)_{2}\right]$} & $45.52 \pm 0.12$ & \\
\hline
\end{tabular}

a Phenolate oxygen group, ${ }^{\mathrm{b}}$ carboxylate oxygen group.

al. had suggested the formation of a mononuclear phenolate complex of $\mathrm{Cu}^{2+}$ and the phenol iminodiacetate ligand HBIDA at $\mathrm{pH}$ above 6.0 (Scheme 1), but they have not mentioned the possibility of dimeric binuclear species in solution [24]. However, recently Stylianou et al. [25] have isolated and crystallographically characterized the dimeric species $\left[\mathrm{Cu}_{2}(\mathrm{Hcacp})_{2}\right]^{2-}$ from aqueous solution at alkaline pHs 8.0-9.0, indicating that such species are present in solution. In this complex the two $\mathrm{Cu}^{2+}$ are bridged through the deprotonated phenolate oxygen (Scheme 2). The speciation diagram of $\mathrm{Cu}(\mathrm{II})-\mathrm{H}_{4}$ cacp system in Figure 3 shows that $\left[\mathrm{Cu}_{2}(\mathrm{Hcacp})_{2}\right]^{2-}$ is the major complex at $\mathrm{pH}$ range $7.0-$ 8.5 reaching a maximum of $20 \%$ of the total metal ion concentration at $\mathrm{pH} 8.0$ and an overall stability formation constant $11.26 \pm 0.02$ equation (2).

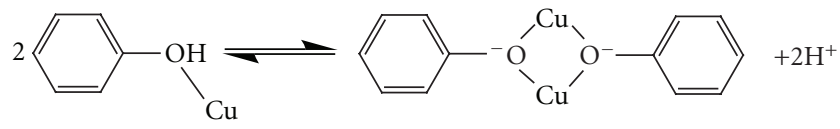

3.3. $\mathrm{Cu}(\mathrm{II})-\mathrm{H}_{6}$ bicah. The $\mathrm{Cu}(\mathrm{II})-\mathrm{H}_{6}$ bicah titration curves were evaluated on the assumption of the formation of various $1: 1$ and 2:1 metal chelates with different protonation steps. The best fit between the simulated curves and the experimental data (Figure 2(b)) was obtained by the speciation model listed in Table 2. Species distribution curves for the complexes formed in the $\mathrm{Cu}(\mathrm{II})-\mathrm{H}_{6}$ bicah system as a function of $\mathrm{pH}$ are depicted in Figure 4. In contrast to $\mathrm{H}_{4}$ cacp, $\mathrm{H}_{6}$ bicah exhibits two metal binding sites, thus, the ligand may ligate up to two metal ions. The potentiometric study shows that the $1: 1$ species are unstable and the equilibrium is favoured only to the formation of $2: 1$ metal to ligand complexes. In addition, the binucleating ligand, $\mathrm{H}_{6}$ bicah, exhibits larger steric hindrance than $\mathrm{H}_{4}$ cacp and thus does not form $\mathrm{O}_{\text {phenolate-bridged complexes with }}$ $\mathrm{Cu}^{2+}$ in solution or in solid state. At $\mathrm{pH}$ above 9.5 the di- and mono-hydroxo complexes $\left[\mathrm{Cu}_{2}(\text { bicah })(\mathrm{OH})_{2}\right]^{4-}$ and $\left[\mathrm{Cu}_{2}(\text { bicah })(\mathrm{OH})\left(\mathrm{H}_{2} \mathrm{O}\right)\right]^{3-}$ are the major species with stability formation constants $11.57 \pm 0.15$ and $15.72 \pm 0.11$, respectively. The brown $\left[\mathrm{Cu}_{2} \text { (bicah) }\left(\mathrm{H}_{2} \mathrm{O}\right)_{2}\right]^{2-}$ is the major species between $\mathrm{pH} 7.0$ and 9.5 and the green monoprotonated $\left[\mathrm{Cu}_{2}(\mathrm{Hbicah})\left(\mathrm{H}_{2} \mathrm{O}\right)_{2}\right]^{-}$at $\mathrm{pH}$ range 5.0 to 7.0 . The second phenol is protonated at $\mathrm{pH}$ below 5.0 resulting in the formation of the blue neutral $\left[\mathrm{Cu}_{2}\left(\mathrm{H}_{2}\right.\right.$ bicah $\left.)\left(\mathrm{H}_{2} \mathrm{O}\right)_{2}\right]$ which has been previously characterized by single crystal Xray crystallography (Scheme 2) [25]. The two $\mathrm{pK}_{a}$ values for the two equilibriums of the stepwise protonation of the two phenolate oxygen atoms equation (3) have been calculated as $5.89 \pm 0.10$ and $6.43 \pm 0.10$ for $\mathrm{pK}_{\mathrm{a} 1}$ and $\mathrm{pK}_{a 2}$, respectively. These values are close to the values $6.25 \pm 0.08$ and $7.19 \pm 0.08$ for $\mathrm{pK}_{a 1}$ and $\mathrm{pK}_{a 2}$, respectively, found by spectrophotometric studies [25]. These differences are observed because the model used for the calculations in the spectrophotometric studies was incomplete (only the equilibriums in (3) were taken into account):

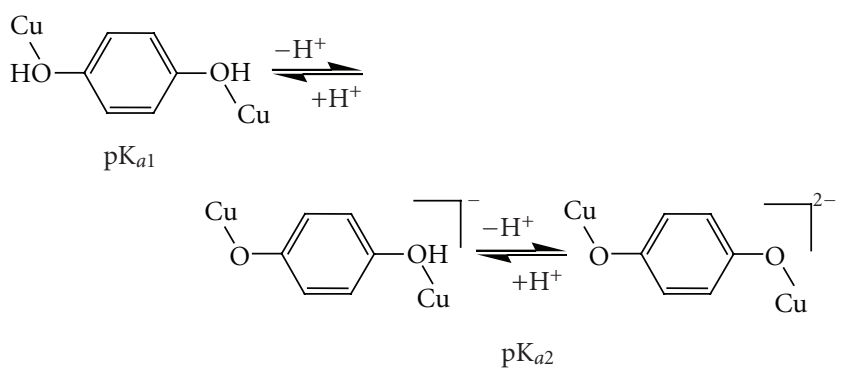

The fact that there is almost $0.5 \mathrm{pK}$ unit difference between the two deprotonation steps indicates that the electronic interaction between the two metal centres through the hydroquinone bridge is significant.

A comparison between the overall stability constants of the two ligands in this study shows that the bifunctional ligand $\mathrm{H}_{6}$ bicah forms more stable complexes than $\mathrm{H}_{4} \mathrm{cacp}$ in solution. This extra stabilization is attributed to the larger increase of entropy expected for the formation of the binuclear $\mathrm{Cu}^{2+}-\mathrm{H}_{6}$ bicah complexes compared to the mononuclear $\mathrm{Cu}^{2+}-\mathrm{H}_{4}$ cacp.

\section{Conclusions}

The speciation of $\mathrm{Cu}^{2+}$ with the iminodiacetic phenol/hydroquinone ligands $\mathrm{H}_{4} \mathrm{cacp} / \mathrm{H}_{6}$ bicah in aqueous solution was investigated by $\mathrm{pH}$-potentiometry. Ligand $\mathrm{H}_{4} \mathrm{cacp}$, at $\mathrm{pH}$ below 5.0 forms with $\mathrm{Cu}^{2+}$ the mononuclear $1: 1$ and $1: 2$ complexes. At higher $\mathrm{pH}$ the phenol proton is deprotonated and at $\mathrm{pH}$ range 5.0-7.0 the major species is the mononuclear $1: 1$ complex. However at $\mathrm{pH} 7.0-8.0$ the formation of a binuclear complex takes place and it is attributed to a $\mathrm{O}_{\text {phenolate-bridged complex. The binucleating }}$ ligand $\mathrm{H}_{6}$ bicah forms only $2: 1$ metal to ligand complexes in the $\mathrm{pH}$ range 2.0 to 9.0 . The major species are the complete phenol protonated complex at $\mathrm{pH}$ below 4.5 , the monoprotonated at $\mathrm{pH}$ range 4.5 to 7.0 , and the complete phenol deprotonated species between $\mathrm{pHs} 7.0$ and 9.0. The $\mathrm{H}_{6}$ bicah did not form binuclear $\mathrm{O}_{\text {phenolate-bridged complex }}$ in solution probably due to steric hindrance originated from the binucleating nature of the ligand. On the other hand, this solution study shows that binuclear $\mathrm{O}_{\text {phenolate-bridged species }}$ 
must also be considered in speciation studies of $\mathrm{Cu}^{2+}$ ions with mononucleating phenolate ligands such as $\mathrm{H}_{4}$ cacp.

\section{Acknowledgments}

The authors thank the Research Promotion Foundation of Cyprus for the financial support of this work with the proposal ANABATHMISH/PAGIO/0308/32. This work dedicated to Professor Nick Hadjiliadis for his retirement.

\section{References}

[1] I. Bento, M. A. Carrondo, and P. F. Lindley, "Reduction of dioxygen by enzymes containing copper," Journal of Biological Inorganic Chemistry, vol. 11, no. 5, pp. 539-547, 2006.

[2] J. L. DuBois and J. P. Klinman, "Mechanism of posttranslational quinone formation in copper amine oxidases and its relationship to the catalytic turnover," Archives of Biochemistry and Biophysics, vol. 433, no. 1, pp. 255-265, 2005.

[3] L. Q. Hatcher and K. D. Karlin, "Oxidant types in copperdioxygen chemistry: the ligand coordination defines the CunO2 structure and subsequent reactivity," Journal of Biological Inorganic Chemistry, vol. 9, no. 6, pp. 669-683, 2004.

[4] M. Mure, "Tyrosine-derived quinone cofactors," Accounts of Chemical Research, vol. 37, no. 2, pp. 131-139, 2004.

[5] S. M. Janes, D. Mu, D. Wemmer, et al., "A new redox cofactor in eukaryotic enzymes: 6-hydroxydopa at the active site of bovine serum amine oxidase," Science, vol. 248, no. 4958, pp. 981-987, 1990.

[6] E. I. Solomon, P. Chen, M. Metz, S.-K. Lee, and A. E. Palmer, "Oxygen binding, activation, and reduction to water by copper proteins," Angewandte Chemie International Edition, vol. 40, no. 24, pp. 4570-4590, 2001.

[7] L. M. Mirica, X. Ottenwaelder, and T. D. P. Stack, "Structure and spectroscopy of copper-dioxygen complexes," Chemical Reviews, vol. 104, no. 2, pp. 1013-1045, 2004.

[8] E. I. Solomon, F. Tuczek, D. E. Root, and C. A. Brown, "Spectroscopy of binuclear dioxygen complexes," Chemical Reviews, vol. 94, no. 3, pp. 827-856, 1994.

[9] J. W. Whittaker, "Free radical catalysis by galactose oxidase," Chemical Reviews, vol. 103, no. 6, pp. 2347-2363, 2003.

[10] J. P. Klinman, "Mechanisms whereby mononuclear copper proteins functionalize organic substrates," Chemical Reviews, vol. 96, no. 7, pp. 2541-2561, 1996.

[11] E. I. Solomon, U. M. Sundaram, and T. E. Machonkin, "Multicopper oxidases and oxygenases," Chemical Reviews, vol. 96, no. 7, pp. 2563-2605, 1996.

[12] G. T. Babcock and M. Wikstrom, "Oxygen activation and the conservation of energy in cell respiration," Nature, vol. 356, no. 6367, pp. 301-309, 1992.

[13] Z. He, S. B. Colbran, and D. C. Craig, "Could redox-switched binding of a redox-active ligand to a copper(II) centre drive a conformational proton pump gate? A synthetic model study," Chemistry-A European Journal, vol. 9, no. 1, pp. 116-129, 2003.

[14] C. L. Foster, X. Liu, C. A. Kilner, M. Thornton-Pett, and M. A. Halcrow, "Complexes of 2-hydroxy-5-methyl-1,4benzoquinone as models for the 'TPQ-on' form of copper amine oxidases," Journal of the Chemical Society, Dalton Transactions, no. 24, pp. 4563-4568, 2000.

[15] P. Li, N. K. Solanki, H. Ehrcnbcrg, et al., "Copper(n) complexes of hydroquinone-containing Schiff bases. Towards a structural model for copper amine oxidases," Journal of the Chemical Society, Dalton Transactions, no. 10, pp. 1559-1565, 2000.

[16] J. A. Halfen, B. A. Jazdzewski, S. Mahapatra, et al., "Synthetic models of the inactive copper(II)-tyrosinate and active copper(II)-tyrosyl radical forms of galactose and glyoxal oxidases," Journal of the American Chemical Society, vol. 119, no. 35, pp. 8217-8227, 1997.

[17] D. G. Lonnon, S. T. Lee, and S. B. Colbran, "Valence tautomerism and coordinative lability in copper(II)-imidazolylsemiquinonate anion radical models for the $\mathrm{CuB}$ center in cytochrome c oxidases," Journal of the American Chemical Society, vol. 129, no. 18, pp. 5800-5801, 2007.

[18] F. Michel, F. Thomas, S. Hamman, E. Saint-Aman, C. Bucher, and J.-L. Pierre, "Galactose oxidase models: solution chemistry, and phenoxyl radical generation mediated by the copper status," Chemistry - A European Journal, vol. 10, no. 17, pp. 4115-4125, 2004.

[19] K. D. Karlin, M. S. Nasir, B. I. Cohen, R. W. Cruse, S. Kaderli, and A. D. Zuberbühler, "Reversible dioxygen binding and aromatic hydroxylation in O2-reactions with substituted xylyl dinuclear copper(I) complexes: syntheses and low-temperature kinetic/thermodynamic and spectroscopic investigations of a copper monooxygenase model system," Journal of the American Chemical Society, vol. 116, no. 4, pp. 1324-1336, 1994.

[20] K. Kamaraj, E. Kim, B. Galliker, et al., "Copper(I) and copper(II) complexes possessing cross-linked imidazole-phenol ligands: structures and dioxygen reactivity," Journal of the American Chemical Society, vol. 125, no. 20, pp. 6028-6029, 2003.

[21] R. C. Pratt and T. D. P. Stack, "Mechanistic insights from reactions between copper(II)-phenoxyl complexes and substrates with activated C-H bonds," Inorganic Chemistry, vol. 44, no. 7, pp. 2367-2375, 2005.

[22] B. A. Barry and O. Einarsdottir, "Insights into the structure and function of redox-active tyrosines from model compounds," Journal of Physical Chemistry B, vol. 109, no. 15, pp. 6972-6981, 2005.

[23] C. Drouza and A. D. Keramidas, "Solid state and aqueous solution characterization of rectangular tetranuclear VIV/V-psemiquinonate/hydroquinonate complexes exhibiting a proton induced electron transfer," Inorganic Chemistry, vol. 47, no. 16, pp. 7211-7224, 2008.

[24] W. R. Harris, R. J. Motekaitis, and A. E. Martell, "New Multidentate ligands. XVII. Chelate tendencies of $\mathrm{N}$-(oHydroxybenzyl)iminodiacetic acid $\left(\mathrm{H}_{3} \mathrm{~L}\right)$," Inorganic Chemistry, vol. 14, p. 974, 1975.

[25] M. Stylianou, C. Drouza, Z. Viskadourakis, J. Giapintzakis, and A. D. Keramidas, "Synthesis, structure, magnetic properties and aqueous solution characterization of p-hydroquinone and phenol iminodiacetate copper(ii) complexes," Dalton Transactions, no. 44, pp. 6188-6204, 2008.

[26] M. M. Whittaker, P. J. Kersten, N. Nakamura, J. SandersLoehr, E. S. Schweizer, and J. W. Whittaker, "Glyoxal oxidase from Phanerochaete chrysosporium is a new radical-copper oxidase," Journal of Biological Chemistry, vol. 271, no. 2, pp. 681-687, 1996.

[27] C. Drouza and A. D. Keramidas, "Synthesis and aqueous solution properties of multinuclear oxo-bridged vanadium(IV/V) complexes," Journal of Inorganic Biochemistry, vol. 80, no. 1-2, pp. 75-80, 2000.

[28] C. Drouza, V. Tolis, V. Gramlich, et al., "p-hydroquinonemetal compounds: synthesis and crystal structure of two novel 
$\mathrm{V}^{\mathrm{V}}$-p-hydroquinonate and $\mathrm{V}^{\mathrm{IV}}$-p-semiquinonate species," Chemical Communications, no. 23, pp. 2786-2787, 2002.

[29] P. Gans and B. O'Sullivan, "GLEE, a new computer program for glass electrode calibration," Talanta, vol. 51, no. 1, pp. 3337, 2000.

[30] A. E. Martell and R. J. Motekaitis, "Potentiometry revisited: the determination of thermodynamic equilibria in complex multicomponent systems," Coordination Chemistry Reviews, vol. 100, pp. 323-361, 1990.

[31] A. E. Martell and R. J. Motekaitis, Determination and Use of Stability Constants, Wiley-VCH, New York, NY, USA, 2nd edition, 1992.

[32] L. Zekany and I. Nagypal, Eds., Computational Methods for the Determination of Stability Constants, Plenum, New York, NY, USA, 1985.

[33] R. P. Bonomo, R. Cali, F. Riggi, E. Rizzarelli, S. Sammartano, and G. Siracusa, "Thermodynamic and spectroscopic properties of mixed complexes in aqueous solution. Copper(II) complexes of 2,2'-bipyridyl and iminodiacetic or pyridine2,6-dicarboxylic acid," Inorganic Chemistry, vol. 18, no. 12, pp. 3417-3422, 1979.

[34] F. L'Eplattenier, I. Murase, and A. E. Martell, "New multidentate ligands. VI. Chelating tendencies of N,N'-di (2hydroxybenzyl) ethylenediamine-N, $\mathrm{N}^{\prime}$-diacetic acid," Journal of the American Chemical Society, vol. 89, no. 4, pp. 837-843, 1967.

[35] R. L. Gustafson and A. E. Martell, "Hydrolytic tendencies of metal chelate compounds. V. Hydrolysis and dimerization of copper(II) chelates of 1,2-diamines," Journal of the American Chemical Society, vol. 81, no. 3, pp. 525-529, 1959.

[36] R. M. Tichane and W. E. Bennett, "Coordination compounds of metal ions with derivatives and analogs of ammoniadiacetic acid," Journal of the American Chemical Society, vol. 79, no. 6, pp. 1293-1296, 1957. 


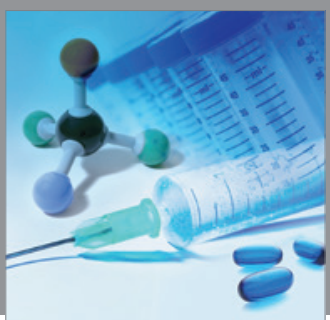

International Journal of

Medicinal Chemistry

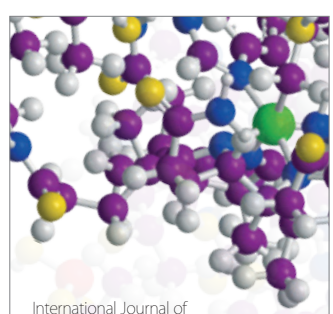

Carbohydrate Chemistry

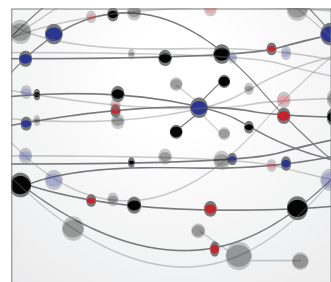

The Scientific World Journal
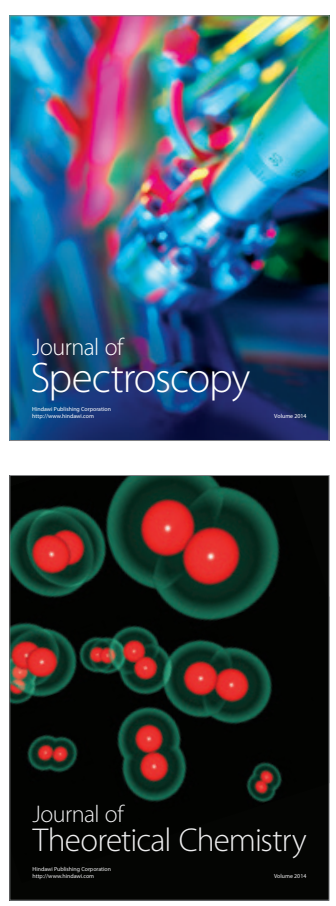
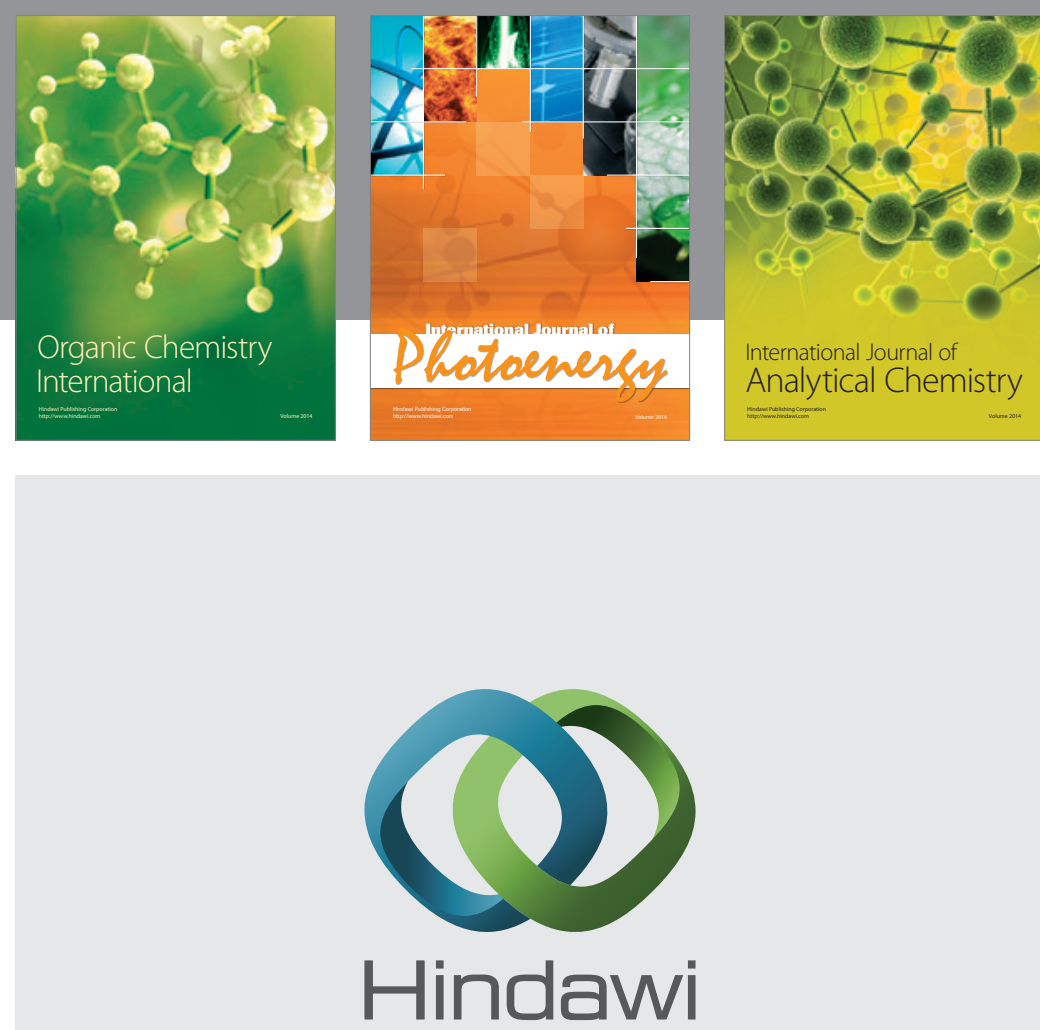

Submit your manuscripts at

http://www.hindawi.com
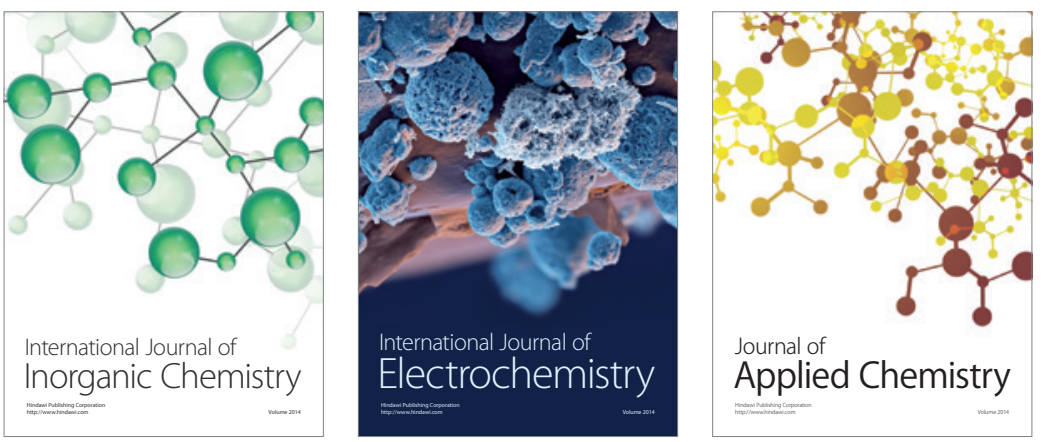

Journal of

Applied Chemistry
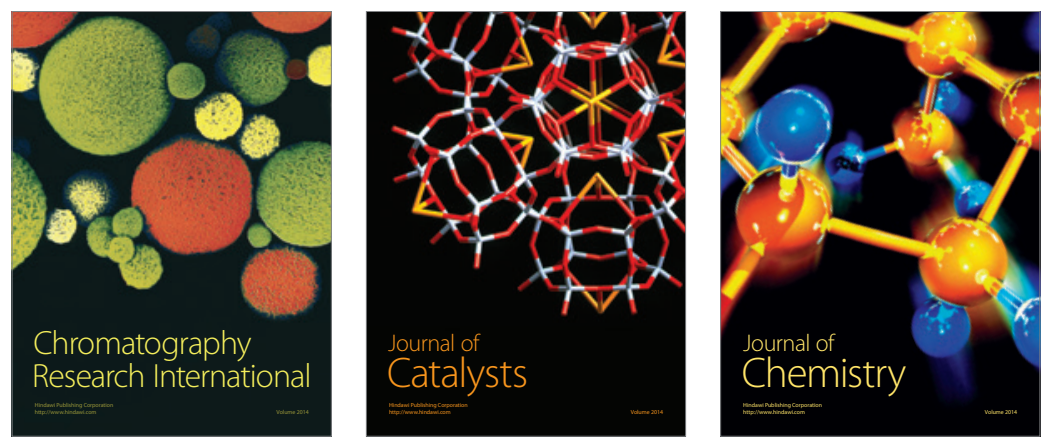
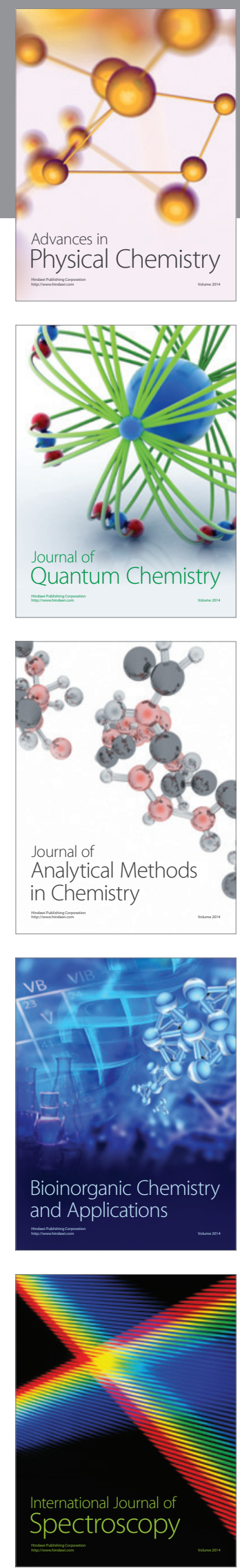